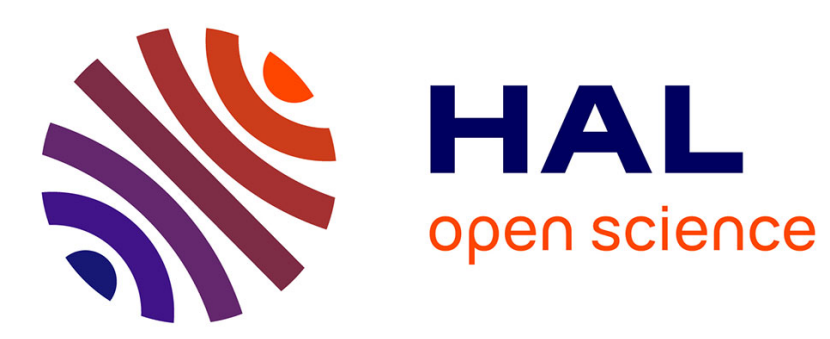

\title{
Systemic sclerosis: An update in 2016
}

Anne Claire Desbois, Patrice Cacoub

\section{To cite this version:}

Anne Claire Desbois, Patrice Cacoub. Systemic sclerosis: An update in 2016. Autoimmunity Reviews, 2016, 15 (5), pp.417-426. 10.1016/j.autrev.2016.01.007 . hal-01297570

\section{HAL Id: hal-01297570 https: / hal.sorbonne-universite.fr/hal-01297570}

Submitted on 4 Apr 2016

HAL is a multi-disciplinary open access archive for the deposit and dissemination of scientific research documents, whether they are published or not. The documents may come from teaching and research institutions in France or abroad, or from public or private research centers.
L'archive ouverte pluridisciplinaire HAL, est destinée au dépôt et à la diffusion de documents scientifiques de niveau recherche, publiés ou non, émanant des établissements d'enseignement et de recherche français ou étrangers, des laboratoires publics ou privés. 
Systemic sclerosis: An update in 2016

\section{Anne Claire Desbois ${ }^{1}$, Patrice Cacoub ${ }^{1}$}

${ }^{1}$ Sorbonne Universités, UPMC Université Paris 06, UMR 7211, and InflammationImmunopathology-Biotherapy Department (DHU i2B), F-75005, Paris, France; ${ }^{2}$ INSERM, UMR_S 959, F-75013, Paris, France; ${ }^{3}$ CNRS, FRE3632, F-75005, Paris, France; ${ }^{4}$ AP-HP, Groupe Hospitalier Pitié-Salpêtrière, Department of Internal Medicine and Clinical Immunology, F-75013, Paris, France

Key words: systemic sclerosis, autoimmune disease, treatment

This paper includes: 6,112 words, abstract 128 words, 107 references, 3 tables.

Correspondence should be addressed to: Prof. Patrice Cacoub, MD, AP-HP, Hôpital PitiéSalpêtrière, Department of Internal Medicine and Clinical Immunology, 83 boulevard de l’hôpital. F-75013, Paris, France

Phone: + (33)(0)1 421780 09. Fax: + (33)(0)1 42178033.

Email: patrice.cacoub@aphp.fr.

Conflict of interest: None 


\begin{abstract}
Systemic sclerosis ( $\mathrm{SSc}$ ) is a chronic immune disorder of unknown origin, dominated by excessive fibrosis responsible for cutaneous and pulmonary fibrosis, and by vascular endothelial dysfunction at the origin of skin ischemia, renal and pulmonary artery lesions. Renal and pulmonary complications are mainly responsible for the severity of the disease. Recent advances led to a better understanding of pathological mechanisms and a more accurate classification of patients according to clinical and biological (auto-antibodies) phenotype. Recent trials provided interesting data on different therapeutic strategies, depending on organ involvement. These data are of particular importance in such disease, still characterized by increased mortality and morbidity rates. In this review, we aim to synthetize recent advances in diagnosis and prognosis leading to better classification of SSc patients, and in therapeutic management.
\end{abstract}

\title{
Key points:
}

- Recent revised classification criteria of the American College of Rheumatology provide important advances to identify early SSc patients or SSc patients with unusual features.

- Biological markers (autoantibodies) are useful to better define the phenotype and the prognosis of SSc patients.

- Based on better understanding pathophysiology, targeted therapies (anti-fibrotic agents, anti-CD20 antibodies...) are currently investigated, depending on organ involvement. 
Systemic sclerosis (SSc) is a chronic immune disorder of unknown origin, characterized by vascular damages and extensive fibrosis. Women are more frequently affected. It is the auto-immune rheumatic disease with the highest disease-related mortality and morbidity with an impaired quality of life [1]. Diffuse SSc cases, defined by a skin thickening involving the proximal limbs or trunk, have a higher frequency of heart, lung or kidney involvement. There have been advances in understanding of pathogenesis. This remains incompletely understood but has reached a point where key cell types and potential mediators can be defined and has started to inform clinical development and trials. Consequently, there have been advances in the management of systemic sclerosis that have led to better overall survival, especially for the most severe diffuse form of the disease. In this review, we aim to synthetize recent advances in diagnosis, in prognosis leading to better classification of SSc patients and in therapeutic management.

\section{Clinical features}

In the EUSTAR register on 9,149 SSc patients, the female/male sex ratio was 6 [2]. Female prevalence was lower in patients with a diffuse cutaneous form (4/1) and young patients (8:1 before 30 years vs. 5:1 after 60 years). Main features of SSc are indicated in Table 1, according to clinico-biological phenotypes of the disease. Besides these specific symptoms, SSc is associated with a high frequency of fatigue, depression, sleeping disorders and sexual dysfunction that also lead to disability and a reduced quality of life[1,3].

\section{Skin lesions}

The Raynaud's phenomenon is almost constant (95\%). It often precedes other signs of scleroderma. It is bilateral and can also affect feet, nose and ears. The capillaroscopy helps clinicians to evoke a SSc pattern (see diagnosis section). In prospective registries of patients followed for a Raynaud's phenomenon (VEDOSS cohort, EUSTAR study), the association of puffy fingers and antinuclear antibodies showed a positive predictive value of $88 \%$ for 
developing scleroderma [4]. Skin thickening begins in fingers (sclerodactily), extending proximal to metacarpophalangeal joints. The extension and degree of sclerosis is quantified using the modified Rodnan score [5]. Cutaneous sclerosis can affect the limbs, the back and the face. The fibrosis limits mouth opening and makes the face inexpressive. Digital ulcers and fingertip pitting scars are found in $42 \%$ of diffuse scleroderma and $33 \%$ in the limited forms. They can lead to a severe discomfort such as pain, infection, functional impairment, gangrene and amputation [6,1]. In a recent study from EUSTAR database ( $n=4,288 \mathrm{SSc})$, the presence of digital ulcers at presentation was associated with worsening of cardiovascular status (elevated systolic arterial pulmonary pression and left ventricular failure) and decreased survival [7]. Many other cutaneous signs are frequently found as limbs ulcerations (40\%), telangiectasia (75\%), hyperpigmentation of thickened skin (30\%), and cutaneous calcifications affecting soft tissues, fingers, forearms, elbows and knees (25\%). Less frequently, patients may present achromic areas.

\section{Pulmonary involvement}

Main pulmonary manifestations of scleroderma include interstitial lung disease and pulmonary hypertension, with or without lung fibrosis. The pulmonary hypertension (defined as a mean pulmonary arterial pressure $>25 \mathrm{mmHg}$ [8] may be secondary to vascular disease associated to scleroderma (SSc-PAH), or to pulmonary fibrosis, with different prognosis.

The pulmonary arterial hypertension, related to direct vascular involvement of scleroderma (PAH-SSc), is defined by a capillary pressure equal or less than $15 \mathrm{mmHg}$. It is related to the occlusion and the remodelling of small pulmonary arterioles. The prevalence of PAH-SSc is variable according to the screening tool, found in $8-12 \%$ of patients when using right catheterization and in up to $38 \%$ when using echocardiography $[9,10]$. In a French prospective study, the incidence of SSc-PAH was 0.61/100 person-years [10]. The symptoms are non-specific, consisting in dyspnoea, chest pain or syncope. In SSc patients, main risk 
factors for developing a pulmonary arterial hypertension are summarized in Table 2 [11]. The major poor prognostic factors of SSc-PAH include impaired function of the right ventricle at diagnosis, the presence of a pericardial effusion and a decreased cardiac output. Making early SSc-PAH diagnosis remains a challenge in order to initiate early the appropriate treatment and to improve the prognosis. Recently, a new algorithm (DETECT study) was proposed to reduce the rate of undiagnosed SSc-PAH [12]. Indeed, among patients with a high risk of PAH [i.e. more than 3 years of SSc evolution, DLCO (Diffusing Capacity of Carbon Monoxyde) <60\%, FVC (Forced Vital Capacity) >40\%] and a diagnosis on right catheterization, $36 \%$ had a tricuspid regurgitation velocity below $2.8 \mathrm{~mm} / \mathrm{s}$ on echocardiography. This algorithm showed negative and positive predictive values of $98 \%$ and $35 \%$, respectively. Only $4 \%$ of SSc-PAH patients would not have been diagnosed while a right catheterization would have been performed in $62 \%$ of patients and negative for $65 \%$. With current recommendations of the European Society of Cardiology, 29\% of SSc-PAH patients would not have been diagnosed and right catheterization would have been performed in $40 \%$ patients [12].

The prevalence of pulmonary parenchymal lesions is variable depending on the subgroups studied (25 to 90\%) [11]. The cutaneous diffuse disease with positive anti-Scl70 antibody is known to be associated with interstitial lung disease [6]. In a large study including more than 3,500 SSc patients, $50 \%$ of patients with diffuse SSc showed interstitial lung disease versus $34 \%$ of those with a limited form [6]. Factors associated with the occurrence of pulmonary fibrosis were diffuse cutaneous form [relative risk (RR 1.7)], the presence of antitopoisomerase I antibodies (RR 1.8), a forced vital capacity <65\% (RR 3.2) and a DLCO $<55 \%$ (RR 3.0) [13]. The most frequently described features include a nonspecific interstitial pneumonia pattern (NSIP) and a pulmonary fibrosis pattern [usual interstitial pneumonia (UIP)]. Among 22 patients with scleroderma and pulmonary interstitial disease who had a 
pulmonary histology, $64 \%$ had a NSIP pattern and $36 \%$ a UIP pattern, with a median survival of 15 versus 3 years, respectively [14]. The presence of an extensive pulmonary fibrosis, defined by lesions extent above $20 \%$ on high resolution-CT scan and/or FVC below $70 \%$, was associated with a 5-year mortality rate of $60 \%$ [15].

\section{Digestive involvement}

An oesophageal involvement concerns $70 \%$ of SSc patients. The symptoms include retrosternal burns, dysphagia, atypical chest pain, nausea, vomiting, regurgitation... They are mostly related to gastro-oesophageal reflux or peristaltic disorders of the oesophagus. They are revealed on oesophageal manometry by a decreased amplitude of contractions in the lower third of the oesophagus and a hypotonic lower oesophageal sphincter (which can lead to oesophagus dilatation). Gastric motility disorders (25\%) may lead to food stasis. Gastric bleeding are rare and may be related to telangiectasia sometimes leading to a so-called "watermelon" stomach. The small intestine involvement (20\%) can result in a chronic intestinal pseudo-obstruction syndrome and/or a malabsorption promoted by bacterial overgrowth. The findings of a recent study suggest that fecal calprotectin may be a helpful test in identifying the group of SSc patients at high risk for small intestinal bacterial overgrowth (SIBO) requiring glucose breath tets and to assess SIBO eradication [16]. A colic involvement is less frequent and is responsible for constipation, colic pain, alternating diarrhea and constipation. Anal incontinence may be observed.

\section{Heart involvement}

The cardiac involvement, probably underestimated, concerns the pericardium and myocardium. The pericardial disease is manifested by acute pericarditis, chronic pericarditis and rarely constrictive pericarditis. Myocardial damages are most often linked to ischemic injury associated to disorders of the coronary microcirculation that may lead to myocardial fibrosis. Up to $60 \%$ of patients showed perfusion defects on myocardial scintigraphy [15]. In 
a large international series of 3,656 SSc patients, $24-27 \%$ of patients had palpitations, $11-13 \%$ a conduction block, $15 \%$ a diastolic dysfunction and $5 \%$ a reduced left ventricular systolic function [6]. In a French multicenter study of 570 SSc patients, $22 \%$ had left ventricular hypertrophy and $17 \%$ a diastolic dysfunction [17].

\section{Articular involvement}

Joint involvement is very frequent (45-90\%), including arthralgia and less frequently symmetrical arthritis, affecting small joints of the hands, wrists, knees and ankles. Joint stiffness may also be related to the cutaneous thickening or to calcified peri-arthritis. Arthritis are usually non-erosive. Synovitis and tendon friction rubs are more common in diffuse cutaneous forms [4], and are associated with rapid skin progression and early kidney disease onset [18]. Osteolysis of the distal phalanx of the fingers is present in $20 \%$ of patients.

\section{Kidney disease}

Renal involvement is a rare (4-6\%) but severe manifestation in patients with SSc and is more frequent in cutaneous diffuse (4\%) than in cutaneous limited form (2\%) [4]. Severe hypertension (90\%), sometimes associated with hypertensive encephalopathy or heart failure, rapid deterioration of renal function and thrombotic microangiopathy (40\%), are the main manifestations of scleroderma renal crisis. Biological abnormalities include frequently nonnephrotic proteinuria, hematuria and moderate thrombocytopenia. Scleroderma renal crisis is defined by: (i) a severe or worsening arterial hypertension $>150 / 85 \mathrm{mmHg}$ twice in twenty four hours, without another explanation AND (ii) a rapidly progressive kidney failure, sometimes oligo-anuric, without further explanation $[19,20]$. The elements supporting the diagnosis are the presence of mechanic hemolytic anemia, hypertensive retinopathy, renal sodium overload or pulmonary oedema, oligo-anuria and suggestive abnormalities on renal biopsy. The typical renal lesion is the "onion bulb" aspect related to endothelial injury, associated with intimal proliferation and vascular remodeling, leading to the obstruction of the 
vascular lumen and to the reduction of glomerular filtration rate. Platelet activation is observed, leading to the formation of thrombosis. The lesions are localized in small and medium arteries, i.e. arterioles and inter-lobular arched, with adventitial fibrosis and intraglomerular thrombosis. The main risk factors of scleroderma renal crisis are a diffuse and rapidly progressive cutaneous form, the presence of anti-RNA polymerase III antibodies, a new onset of anemia, a recent cardiovascular event, the administration of high doses of corticosteroids (> 15mg per day) and a recent development of scleroderma ( $<4$ years) $[15,16]$.

\section{Neurological involvement}

In a recent meta-analysis on 6,028 SSc patients, 177 (2.9\%) patients had a central neurological disorder. Main reported features included headache (23.7\%), epilepsy (13.6\%), and cognitive disorders (8.5\%). In addition, $442(7.3 \%)$ patients presented with a peripheral neuromuscular disorder, i.e. myopathy, trigeminal nerve disorder, motor and sensory neuropathy and carpal tunnel syndrome [21]. Psychiatric signs were found in 1,490/2,712 $(54.9 \%)$ patients, consisting in depressive symptoms (73.2\%) and anxiety (23.9\%).

\section{Specific forms}

\section{Scleroderma sine scleroderma}

Scleroderma without skin thickening is an uncommon form of the disease (2-8\%). Such pattern may be related to an initial misclassification of patients with a discrete skin disease and a relatively slow evolution. Patients with scleroderma sine scleroderma share clinical features with those with cutaneous limited form, i.e. lower frequency of telangiectasia, digital ulcers, anti-topoisomerase I and anti-RNA polymerase III antibodies. However, anticentromere antibodies are frequently observed. The prevalence of visceral involvements seems similar in forms with or without skin sclerosis i.e. oesophageal disorders $(56-83 \%)$, lung involvement (25-57\%), and scleroderma renal crisis $(2.5-3.7 \%)[22,23]$. 
Muscular involvement

Patients with anti-PmScl antibodies have overlap syndromes between myositis and scleroderma. They are more likely to have myopathy and pulmonary disease [24]. Patients with scleroderma and anti-PmScl antibodies had fewer digital ulcers and cutaneous thickening or diffuse form while they had better pulmonary prognosis [25]. In the EULAR register [6], muscle weakness and creatinine phosphokinase increase were significantly associated to diffuse cutaneous form (37.1\% vs. $11.3 \%)$ and anti-Scl70 antibodies (32.2\% vs. $8.7 \%$ ). Myopathy predicted deaths of all origins and scleroderma-related deaths [2]. A creatinine phosphokinase increase was associated with the development of heart disease [RR 2.64 (95CI $1.2 ; 5.81)]$.

\section{Pathophysiology of systemic sclerosis}

Systemic sclerosis is characterized by vasculopathy, fibrosis and inflammation. To date, mechanisms contributing to fibrosis and vasculopathy are not completely elucidated.

Environmental factors may contribute to SSc occurrence. SSc occurrence was associated with silica exposure, chlorinated solvents, trichloroethylene, welding fumes for men, aromatic solvents and ketones for women and white spirit for both genders [26]. In U.S cohorts, first degree relatives were identified to have increased susceptibility to develop SSc with a RR 10 to 16. Several studies found an association between SSc and genes implicated in immune system, notably polymorphisms of the interferon-regulatory factor 5 (IRF5) involved in activation of interferon targets and the ligand of CD134 (OX40L) involved in antigen presentation and $\mathrm{T}$ and $\mathrm{B}$ cells activation. The combination of signal transducer and activator of transcription 4 (STAT4) and IRF5 was associated with an increased risk of pulmonary fibrosis occurrence. Genome wide association studies identified an association with a variant of c-src tyrosine kinase (CSK) which modulates signalling through the T-cell receptor and 
CD247 (encoding a sub-unit of the $\mathrm{T}$ cell receptor) [27,28]. Other studies have shown an association between BANK1 (B-cell gene) variants and diffuse phenotype of SSc in Caucasians, confirming the major role of B cells $[29,30]$. Studies of polymorphisms of the Major Histocompatibility Complex found associations with SSc in Caucasians and Hispanics for DRB1*1104, DQA1*0501, and DQB1*0301 [31]. In addition, DRB1*1101 and DPB1*1301 alleles were associated with the presence of anti-topoisomerase I antibodies while DRB1*0401-22 and DRB1*0801-11 alleles were associated with anti-centromere antibodies. [32]

SSc patients display arterial hyper-reactivity and remodelling with myo-intimal proliferation, which can lead to arterial occlusion in skin, heart, lung and kidney. Several mechanisms have been proposed to explain perturbation of vascular tone. Increased endothelin-1 levels, known to enhance vasoconstriction, inflammation and vascular remodelling, were found in sera, lung or kidney biopsies as well as defective prostacyclin synthesis. Patients with diffuse SSc, without fingertips ulcers and anti-Scl70 antibody positive were found to have higher levels of vascular epidermal growth factor (VEGF) compared with healthy controls and SSc patients with digital ulcers [33]. Excess levels of VEGF have been shown to aggravate fibrosis and might lead to impaired angiogenesis [34]. Increased serum levels of the anti-angiogenic VEGF165b isoform have been reported which could explain the lack of sufficient angiogenesis despite elevated VEGF levels [35]. Sufficient angiogenesis depends on the tight regulation of VEGF expression. Prolonged exposure may have deleterious effects on angiogenesis while very high concentrations of pro-angiogenic VEGF isoforms are needed to overcome the inhibitory effects of anti-angiogenic factors (to have beneficial effects in the prevention and therapy of fingertip ulcers). Elevated levels of pentraxin 3 was found as an independent factor associated with the presence of digital ulcers and pulmonary hypertension and as a predictor of future occurrence of new digital ulcers, suggesting its suppressing effect 
on vasculogenesis [36]. Increased MCP-1 (Monocyte Chemoattractant Protein 1) and VCAM1 (Vascular Cell Adhesion Molecule 1) expressions by endothelial cells enhance leucocytes recruitment and promote inflammation. Anti-endothelial cell antibodies have been reported to induce endothelial cell apoptosis [37].

Oxidative stress plays a major role in the pathogenesis of SSc. Endothelial cells and fibroblasts exposure to sera of SSc patients has been shown to induce Reactive Oxygen Species (ROS) production, which is associated to increased fibroblasts proliferation. SSc is characterized by collagen accumulation in skin, the consequence of fibroblast activation. Phenotypical changes of fibroblasts in SSc have been observed, with an increase of differentiation into myo-fibroblasts. Transforming growth factor (TGF- $\beta$ ) plays a major role in fibroblast activation and phenotypical modifications. Increased TGF- $\beta$ levels have been shown in lung and dermal SSc lesions [38]. Other actors as the platelet derived growth factor (PDGF-R) and the connective tissue growth factor (CTGF) are involved in late stage fibrosis development in scleroderma. IL-4, a Th-2 cytokine, is pro-fibrotic and has been shown to be increased in SSC patient sera. It is over-expressed by activated $\mathrm{TCD} 8^{+}$lymphocytes in bronchoalveolar fluid and skin of SSc patients [39,40].

Immune system is also implicated in vasculopathy and in skin fibrosis observed in SSc patients. The presence of specific auto-antibodies (anti-centromere, anti-topoisomerase I, anti-RNA polymerase III...) indirectly suggests a role of B cells in the SSc pathogenesis. SSc patients display phenotypical changes of B cells, with over-expression of CD19 and CD21 [two activation co-receptors of the B cell receptor (BCR)] and of CD86 and CD95 in memory B cells [41]. Levels of anti-endothelin A receptor and anti-angiotensin type 1 receptor antibodies were significantly higher in patients with SSc-PAH $(n=81)$ and connective tissue disease-associated PAH $(n=110)$ compared with other forms of PAH/pulmonary hypertension $(\mathrm{n}=106)$. High levels of angiotensin type 1 receptor and endothelin A receptor antibodies 
predicted the development of SSc-PAH and SSc-PAH-related mortality. The transfer of SScIgG containing both auto-antibodies into healthy $\mathrm{C} 57 \mathrm{BL} / 6 \mathrm{~J}$ mice led to more abundant vascular and airway $\alpha$-smooth muscle actin expression and inflammatory pulmonary vasculopathy [42]. Serum levels of IL-6 levels, known to stimulate collagen secretion by fibroblasts, were also found to be increased in SSc patients and correlated with skin fibrosis [43]. TNF $\alpha$ also plays a role in the recruitment of inflammatory cells. T cells also appear to be involved in mechanisms of SSc, with a Th-2 bias leading to IL-4 and IL-13 secretion and B cells stimulation. IL-4 antibody might prevent skin fibrosis [44]. Proteome-wide analysis showed that CXCL4 is the predominant protein secreted by plasmacytoid dendritic cells in systemic sclerosis, especially in early SSc, both in the circulation and in the skin. High levels of CXCL4 were associated with lung fibrosis and pulmonary hypertension. CXCL4 predicted the risk of progression of systemic sclerosis. In vitro, CXCL4 induces endothelin-1 and potentiates responses of toll-like receptors. In vivo, CXCL4 induces the influx of inflammatory cells and skin thickening [45].

\section{Biomarkers, diagnostic criteria and prognostic factors}

\section{a. Biomarkers}

The most frequently found autoantibodies are anti-centromere (ACA) in 15-43\% of patients, anti-topoisomerase I (anti-Scl70) in 21-34\%, anti-RNA polymerase III in 5\% and anti-RNP in $5 \%[46,47]$. Anti-Scl70 antibodies were positive in $47 \%$ of diffuse cutaneous forms versus $14 \%$ of limited cutaneous forms, whereas anti-centromere antibodies were found only in limited forms (69\%) [48]. The ACA prevalence varies from one population to another, with lower rates among African/Americans. The ACA are associated with limited cutaneous forms and with a longer time to onset of visceral complications. Patients ACA-positive often have pulmonary hypertension, but have less frequently digital ulcers, parenchymal lung disease, 
myocardial and kidney involvements and lower mortality rate [46]. Anti-Scl70 (antitopoisomerase I) antibodies recognize the $70 \mathrm{kDa}$ protein of topoisomerase $\mathrm{I}$, and are associated with diffuse cutaneous disease. These antibodies appear to be associated with a poor prognosis, increased lung and heart involvements and higher mortality rates. Patients with anti-topoisomerase I antibodies develop Raynaud's phenomenon earlier and have a more severe cutaneous presentation. The prevalence of anti-RNA polymerase III antibodies was $11 \%$ with a great geographical variability, i.e. $20 \%$ in South America,16-20\% in North America, $11-15 \%$ in Asia and $<10 \%$ in Europe. In a recent French study, the anti-RNA polymerase III antibodies overall prevalence was 6 to $9 \%$ in 133 SSc patients, i.e. $11-19 \%$ in diffuse cutaneous versus 3-5\% in limited cutaneous forms [48]. The presence of anti-RNA polymerase I and III is associated with diffuse cutaneous forms (OR 6.4), scleroderma renal crisis (OR 3.8), tendon contractures (OR 2.5) and a cancer diagnosis within the 5 first years after SSc diagnosis (OR 4.2) [49,50]. After a mean follow-up of 1.9 years, in patients without anti-RNA polymerase III antibodies, the probability of occurrence of scleroderma renal crisis and cancer was of 2 and 4\%, respectively [50]. The presence of anti-RNA polymerase III antibodies was significantly associated with the occurrence of cancer, i.e. $14.2 \%$ of patients with anti-RNA polymerase III versus $6.3 \%$ of those with anti-Scl70 and $6.8 \%$ of those with ACA. Patients with anti-RNA polymerase III antibodies were 6 times more likely to have a cancer within 3 years following the first signs of scleroderma [51]. Anti-U1RNP antibodies are found in $90 \%$ of mixed connective disease and are often associated with the presence of other antibodies (anti-SSA, anti-SSB). They are associated with the onset of pulmonary arterial hypertension whereas renal disease is less common. Patients with arterial pulmonary hypertension and anti-U1RNP antibodies have a poorer prognosis than those with ACA [52].

Other autoantibodies are more rarely found in SSc patients. Anti-Th/Tho antibodies (0.2-6\%) are associated with limited cutaneous SSc, renal crisis and a reduced survival rate [53]. 
Patients with anti-Th/Tho antibodies develop more frequently interstitial lung disease and pericarditis but less frequently digital ulcers [53,54]. Anti-Fibrillarin/U3 ribonucleoprotein antibodies (4-18\%) are associated with African/American people, muscular involvement, increased risk of $\mathrm{PAH}$, a younger age at onset, higher frequency of digital ulcers, pericarditis and severe lower gastrointestinal involvement, but less severe lung involvement. The impact of anti-fibrillarin antibodies on survival rates is conflicting $[55,56]$.

\section{b. Diagnostic criteria}

Diagnosis of SSc is based on a set of clinical, immunological (specific antibodies) and capillaroscopic features. The first classification criteria of the American College of Rheumatology in 1980, defined scleroderma by the presence of a proximal cutaneous sclerosis associated with at least 2 of the 3 following criteria: sclerodactyly, digital ulcers, and pulmonary fibrosis. Such criteria did not take into account immunological parameters, patients with limited cutaneous involvement or with an early form. Criteria established by LeRoy et al. in 1988 included capillaroscopic and immunological features. Diffuse forms have been defined as they include a proximal and distal skin thickening, capillary loss on capillaroscopy and the absence of ACA. They are more often associated with antitopoisomerase I antibodies and early visceral involvements as pulmonary, renal, myocardial and gastrointestinal damages. Limited cutaneous forms include a distal skin involvement, systemic vascular disorders such as late onset PAH and a high ACA prevalence. To enable earlier diagnosis, criteria for "early" scleroderma were proposed as Raynaud's phenomenon associated with suggestive capillaroscopic abnormalities and/or the presence of specific antibodies (ACA, anti-Scl70, anti-RNA polymerase III, anti-PmScl or anti Th/To) [57]. Typical capillaroscopic scleroderma abnormalities include the presence of enlarged capillaries and capillary loss with or without peri-capillary haemorrhages. Patients meeting these criteria have a high risk of developing scleroderma in the following twenty years, i.e. $79.5 \%$ for 
patients with Raynaud's phenomenon, specific antibodies and capillaroscopic abnormalities and $35.4 \%$ among those having a Raynaud's phenomenon and specific antibodies without capillaroscopic specific abnormality [58]. Of note, systemic involvement (cardiac, pulmonary, digestive ...) was present in $42 \%$ of patients with an "early" scleroderma [59]. Recently, new classification criteria have been proposed by the EULAR in order to further increase the sensitivity of SSc criteria including early forms or those without skin thickening (Table 3) [47]. These criteria concern patients with a suspicion of scleroderma and exclude patients with cutaneous sclerosis sparing fingers or with a "scleroderma-like disorder" better explained by another disease (i.e. nephrogenic sclerosing fibrosis, generalised morphea, eosinophilic fasciitis, scleredema diabeticorum, scleromyxedema, erythromyalgia, porphyria, lichen sclerosis, graft-versus-host disease, diabetic cheiroarthropathy...).

\section{c. Prognostic factors}

Male gender was significantly associated with some clinical features: myopathy (RR 1.93), diffuse cutaneous forms (RR 1.68), digital ulcers (RR 1.28), pulmonary hypertension (RR 3.01), and proteinuria (RR 1.54). Male gender was also reported to be predictive of new onset of pulmonary hypertension (RR 2.66) and heart failure (RR 2.22) [2].

Data from the EUSTAR database indicated that more than half of deaths are attributed directly to SSc i.e. pulmonary fibrosis (35\%), PAH (26\%) and cardiac causes (26\%). Non-SSc causes of deaths included infections, malignancies and cardiovascular diseases. Independent risk factors for mortality included proteinuria, the presence of PAH on echocardiography, pulmonary restriction or dyspnoea or decreased DLCO, an elevated age at Raynaud's phenomenon onset and an increased modified Rodnan score.

Despite similar hemodynamic indices, patients with SSc-PAH have a higher mortality rate and are less responsive to specific therapy than patients with idiopathic PAH [60]. In the REVEAL register, patients with SSc-PAH ( $n=500)$ showed higher mortality rates than 
patients with non SSc-CTD-PAH (1 year survival of $82 \%$ vs $94-96 \%$ in systemic lupus erythematosus and rheumatoid arthritis) [61]. Predictors of mortality in the SSc-PAH group were male gender, age>60 years, a low systolic blood pressure or 6-min walk distance (6MWD), and a high mean right atrial pressure (mRAP) or pulmonary vascular resistance (PVR) [62].

The extent of lung disease on high resolution CT scan independently predicted both mortality and Interstitial Lung Disease (ILD) progression in SSc patients. Other parameters found to be associated with mortality or ILD progression included male gender, presence of honeycombing, elevated KL-6 values (a mucinous high-molecular weight glycoprotein, expressed on type 2 pneumonocytes) and increased alveolar epithelial permeability $[63,64]$.

\section{Treatment of systemic sclerosis complications}

\section{a. Management of Raynaud's phenomenon (RP) and digital ulcers}

Besides pharmacological treatments, the eviction of aggravation factors remains a major issue. Patients should stop smoking, avoid the use of vasoconstrictive drugs and protect his/her hands against cold and keep them warm. Proximal arterial lesions should be always investigated and treated.

In SSc patients presenting with RP, calcium antagonists are recommended as first line therapy. Intravenous prostanoids should be used in severe refractory RP. Nifedipine and intravenous iloprost reduced the frequency and severity of SSc-RP attacks [65]. One metaanalysis, including six randomised placebo-controlled trials [nifedipine $(n=5), 59$ SSc patients] showed over a 2-week period that calcium antagonists compared with placebo reduced the number of ischaemic attacks by 8.3 (95\% CI 0.9-15.7) and were associated with a $35 \%$ improvement of RP severity score $[65,66]$. A second meta-analysis included five randomized controlled trials with intravenous iloprost, one randomized controlled trial with oral iloprost and one randomized controlled trial with oral cisaprost (332 SSc patients). 
Iloprost i.v. (0.5 to $3 \mathrm{ng} / \mathrm{kg} / \mathrm{min}$ for 3 to 5 consecutive days) or orally (50 to $150 \mathrm{mg}$ twice a day) improved the RP severity score in comparison with placebo. [67]. Two other randomized controlled trials showed that i.v. iloprost ( 0.5 to $3 \mathrm{ng} / \mathrm{kg} / \mathrm{min}$, every 6-8 weeks) was superior to nifedipine (30-60 mg/day) in improving SSc-RP symptoms [68,69]. A meta-analysis analysed main results with PDE-5 inhibitors, including six randomized controlled trials [sildenafil $(n=1)$, modified-release sildenafil $(n=1)$, tadalafil $(n=3)$ vardenafil $(n=1)]$. Use of PDE-5 inhibitors significantly improved Raynaud's score and the daily frequency and duration of RP attacks [70]. Finally, treatment with fluoxetine was shown to be superior to nifedipine to reduce both $\mathrm{RP}$ attack frequency $(\mathrm{P}=0.003)$ and attack severity $(\mathrm{P}=0.0002)$ [71].

For the treatment of SSc-digital ulcers, i.v. iloprost (3 to 5 consecutive days) proved to reduce the number of digital ulcers in comparison with placebo [72]. Bosentan should be considered to avoid ulcers recurrences in patients with multiple digital ulcers, after failure of calcium antagonists. Bosentan (62.5 mg twice a day for 4 weeks, followed by $125 \mathrm{mg}$ twice a day for another 12 weeks) reduced the number of new digital ulcers by $48 \%$ compared to placebo [73]. The efficacy of bosentan was confirmed, especially in diffuse SSc patients with a $61 \%$ reduction of new digital ulcers over 16 weeks [74]. Bosentan did not prove to be effective in healing of SSc-related active digital ulcers. The available evidence concerning calcium antagonists and prostanoids in the prevention of new digital ulcers in SSc patients is less robust and long term clinical experience suggests a good safety profile. A meta-analysis showed a benefit of PDE-5 inhibitors [sildenafil (50 mg or $100 \mathrm{mg}$ ) or tadalafil $(20 \mathrm{mg})$ ] compared to placebo on both digital ulcers healing [RR 3.28 (95CI 1.32-8.13)] and improvement [RR 4.29 (95CI 1.73-10.66)] [75]. The randomized placebo-controlled SEDUCE study showed a significant decrease in the number of digital ulcers in the sildenafil 
group compared with placebo at week8 and week12 [76]. Tociluzimab was shown to be efficient in ulcers healing in some case-reports [77].

\section{b. Kidney involvement}

Glucocorticoids should be avoided as they are associated to scleroderma renal crisis (SRC) occurrence; if absolutely necessary glucocorticoids should be given at low doses $(<15 \mathrm{mg} / \mathrm{d}$ of prednisone). Use of ACE inhibitors remains important for SRC treatment, although controlled data are not available. A case control study of 108 patients with SRC showed that patients on ACE inhibitors had better 1- and 5-years survival rates compared to patients not on ACE inhibitors (76\% vs. $15 \%$ and $66 \%$ vs. $10 \%$, respectively, p=0.001) [78]. An ACE inhibitor treatment should be continued even while the patient is on dialysis, as patients have the potential to improve their renal function after a SRC [79]. Patients who develop a normotensive renal crisis should also receive ACE inhibitors, as these drugs can be lifesaving during acute SRC. A recent prospective cohort showed an increased mortality rate in patients with SRC who were already receiving ACE inhibitors [hazard ratio 2.42 (95CI 1.02-5.75); $\mathrm{p}<0.05$ ] but results were no more significant after adjustment for pre-existing hypertension [hazard ratio 2.17 (95CI 0.88-5.33); p=0.09] [80].

\section{c. Scleroderma-related PAH}

Management of SSc-related PAH remains challenging for clinicians. Most studies included idiopathic PAH with a minority of SSc patients and subgroup analysis were not always performed. Tolerance of treatments, especially combination therapies, might be poorer in SSc patients due to oesophageal dysmotility, gastroparesis, malabsorption, hepatotoxicity, renal disease... Recent findings have shown that variation of 6MWT did not predict change in haemodynamics in SSc patients with PAH [81].

Endothelin receptor antagonists such as bosentan and ambrisentan are associated with improved exercise capacity, hemodynamics and time to clinical worsening in idiopathic-PAH. 
The efficacy of bosentan in SSc patients seems to be less important, with poorer survival rates compared to I-PAH patients [82]. In the SERAPHIN study, macitentan was shown to reduce a composite endpoint that included death, atrial septostomy, lung transplantation, initiation of intravenous prostanoids and worsening of PAH [83]. Treatments implicated in the nitric oxide pathway such as PDE-5 inhibitors [sildenafil, tadalafil] showed increased exercise capacity, hemodynamics and time to clinical worsening in PAH and in the subgroup of CTD-PAH patients. Riociguat, a soluble guanylate cyclase stimulator, enhances the NO-cGMP pathway by stimulating cGMP production. Riociguat showed favourable results on exercise capacity, hemodynamics and time to clinical worsening in PAH including CTD-PAH patients. Of note, the combination of riociguat and PDE-5 inhibitors is contra-indicated (risk of hypotension). Drugs involved in the prostacyclin pathway include i.v. epoprostenol, iloprost and treprostinil. Epopronestol improves exercise capacity, respiratory symptoms and hemodynamics. It is the only treatment that proved to reduce mortality rate in a randomized trial in I-PAH, but not in SSc-PAH patients [84]. The difficulty of administration (infusion pump) can be challenging for patients whose manual dexterity may be impaired. Inhaled iloprost has also been evaluated but requires frequent administration.

Recently Galié et al have proposed a treatment algorithm of PAH, according to World Health Organization functional class [85]. First line treatment should include general measures as rehabilitation and exercise training within symptoms limit, to improve functional capacity and quality of life. However, exercise training may difficult in SSc patients with musculoskeletal involvement with joint and muscle involvements. Anticoagulation is recommended for PAH patients with advanced disease, although the risk of bleeding is increased in SSc patients. Diuretics and oxygen use are recommended. Acute vasoreactivity should be searched in all PAH-patients, and vasoreactive patients should receive calcium channel blockers. However, vasoreactivity concerns only a minority of SSc patients $(<1 \%)$. No evidence-based treatment 
can be proposed in WHO-functional class II or III patients. In WHO-functional class IV patients, i.v. epoprostenol is recommended as first-line therapy and most experts consider other treatments as a second line or in case of impossible use of epoprostenol.

Given the synergic effects of the available specific PAH treatments, combination therapies have become a more common practice. Studies have shown efficacy of combination therapy, notably sildenafil plus bosentan in PAH. A double or triple combination therapy is suggested in case of inadequate clinical response or in severely ill patients (WHO functional class III or IV).

Lung transplantation is the ultimate therapeutic option. Although CTD is not an absolute contraindication to lung transplantation, as SSc patients tend to have multi-organ disease and many comorbidities that increase peri- and post-operative risk and mortality, such approach is rarely feasible.

\section{d. Lung disease}

Cyclophosphamide (CYC) is recommended as first-line therapy in SSc patients with ILD. Two high quality randomized controlled trials tested the efficacy of oral (the Scleroderma Lung Study) [86] or pulse (Fibrosing Alveolitis in Scleroderma Trials) CYC compared to placebo [87]. Tashkin et al, reported in a double blind, randomized placebo-controlled trial on 158 SSc patients with active and symptomatic ILD, that one year of oral CYC had a significant beneficial effect on lung function tests, dyspnea and health-related quality of life. The effects on lung function were maintained through the twenty-four months follow-up [86]. Hoyles et al., in a randomized placebo-controlled trial on 45 ILD-SSc, did not find improvement in the primary (forced vital capacity or DLCO) or secondary end points in the i.v. CYC group [87]. A meta-analysis of three randomized trials and six observational studies did not find significant change in forced vital capacity [2.83\% (95CI $0.35-5.31]$ or DLCO [4.56\% (95CI -0.21-9.33)] after 12 months of CYC therapy (iv or oral) [88]. The efficacy of 
azathioprine or mycophenolate mofetil has been suggested by small cohorts in uncontrolled studies $[14,89,90]$. In patients with severe CTD-ILD (median FVC 44\%) refractory to immunosuppressants, rituximab was found to significantly improve FVC after 12 months [91]. Rituximab has been reported to increase both FVC and DLCO in open-label uncontrolled studies [92,93]. Rituximab prevented further decline of FVC in SSc patients with interstitial lung disease compared with matched controls $(0.4 \pm 4.4 \%$ vs. $-7.7 \pm 3.6 \%$, respectively; $\mathrm{p}=0.02$ ) [94].

Anti-fibrotic agents have been evaluated in SSc associated-lung fibrosis. In a phase I/IIa pilot study [95], Imatinib (up to $600 \mathrm{mg} /$ day) did not show improvement in FVC and DLCO. In addition, five (25\%) patients discontinued the treatment due to imatinib-related adverse events. Imatinib (200 mg/day) have been tested in a phase II study of $30 \mathrm{SSc}$ patients with active ILD unresponsive to CYC. It showed an improvement or stabilization of lung disease in $15 \%$ and $58 \%$ of patients, respectively [96].

\section{e. Skin disease}

Two randomized controlled trials suggested that methotrexate may improve skin scores in early diffuse SSc [65]. Cyclophosphamide has been shown to improve skin fibrosis in a randomized placebo-controlled trial [86]. Mycophenolate mofetil showed, only in uncontrolled trials, to improve significantly skin thickness [97,98]. Intravenous immunoglobulins have been shown to improve skin fibrosis in few case-reports and small size open-label trials [99]. However, Takehara et al., did not demonstrate efficacy of one course of intravenous immunoglobulins compared to placebo in a randomized placebo-controlled trial [100].

Rituximab improved the mean skin score in 20 SSc patients during the 48 months follow-up (mRss $9.8 \pm 7.2$ vs. $22.3 \pm 9.5 ; \mathrm{p}<0.0001$ ). All but one patient experienced an improvement of more than $10 \%$, with a median decrease of $50.2 \%$ [101]. A case-control study in patients with 
severe diffuse SSc showed that mRSS changes were greater in the rituximab group than in controls $(-24.0 \pm 5.2 \%$ vs. $-7.7 \pm 4.3 \%$, respectively; $\mathrm{p}=0.03)[94]$. Other studies confirmed the efficacy of rituximab on SSc skin involvement [93]. Tocilizumab was shown to decrease skin scores in some case-reports [77].

Anti-fibrotic agents have also been evaluated in SSc skin fibrosis. Nintedanib, a tyrosine kinase inhibitor, was able to prevent in a dose-dependent manner bleomycin-induced skin fibrosis in mice and was effective in the treatment of established skin fibrosis. Treatment with nintedanib ameliorated fibrosis in the chronic graft-versus-host disease model and in mice [102]. In an open pilot clinical trial of ten patients with diffuse and early SSc treated with nilotinib (a tyrosine kinase inhibitor), three patients discontinued the treatment due to drugrelated adverse events (two due to nilotinib-related prolonged QTc and one due to coronary artery disease), and seventy one adverse events were observed. The mRSS improved by a mean of 4.2 points $(16 \%)$ at 6 months and by 6.3 points $(23 \%)$ at 12 months $(\mathrm{p}=0.02$ and 0.01, respectively) [103]. An open-label trial evaluated the benefit of fresolimumab (a TGF- $\beta$ inhibitor) in fifteen patients with early diffuse cutaneous SSc. Skin fibrosis dramatically and rapidly decreased after only one injection of $5 \mathrm{mg} / \mathrm{kg}$ or two injections of $1 \mathrm{mg} / \mathrm{kg}$ of fresolimumab. TGF- $\beta$-regulated biomarker genes and dermal myofibroblast infiltration significantly decreased. However, drug-related adverse events were frequent [104].

\section{f. High-dose immunosuppressive therapy and autologous hematopoietic stem cell transplantation}

In phase 1 and small-size phase 2 trials, high-dose immunosuppressive therapy and autologous hematopoietic stem cell transplantation (HSCT) seem promising in the treatment of SSc. Non-myeloablative autologous HSCT improved skin and pulmonary function in 10 patients with SSc, without increase of mortality rate [105]. A phase 3, multicenter, randomized, trial, [Autologous Stem Cell Transplantation International Scleroderma (ASTIS)] 
including 156 patients with early diffuse cutaneous SSc, have evaluated the benefit of HSCT compared to i.v. pulse CYC. HSCT was associated with an increased treatment-related mortality within the first year although it conferred a significantly better long-term event free survival after the first year. HSCT significantly improved some SSc-related involvements at 2 years such as skin thickness and lung disease [106].

In summary, systemic sclerosis is an immune disease dominated by excessive fibrosis responsible for cutaneous and pulmonary fibrosis, and vascular endothelial dysfunction at the origin of skin ischemia, renal and pulmonary artery lesions. Renal and pulmonary complications are responsible for the severity of the disease. The different autoantibodies disease help to better define the phenotype and prognosis of patients. Therapeutic strategy depends on organ involvements. Further prospective and controlled studies are warranted in SSc patients, in particular in lung and pulmonary artery diseases. 


\section{References}

[1] Almeida C, Almeida I, Vasconcelos C. Quality of life in systemic sclerosis. Autoimmun Rev 2015;14:1087-96. doi:10.1016/j.autrev.2015.07.012.

[2] Elhai M, Avouac J, Walker UA, Matucci-Cerinic M, Riemekasten G, Airo P, et al. A gender gap in primary and secondary heart dysfunctions in systemic sclerosis: a EUSTAR prospective study. Ann Rheum Dis 2014. doi:10.1136/annrheumdis-2014-206386.

[3] Bruni C, Raja J, Denton CP, Matucci-Cerinic M. The clinical relevance of sexual dysfunction in systemic sclerosis. Autoimmun Rev 2015;14:1111-5. doi:10.1016/j.autrev.2015.07.016.

[4] Minier T, Guiducci S, Bellando-Randone S, Bruni C, Lepri G, Czirjak L, et al. Preliminary analysis of the Very Early Diagnosis of Systemic Sclerosis (VEDOSS) EUSTAR multicentre study: evidence for puffy fingers as a pivotal sign for suspicion of systemic sclerosis. Ann Rheum Dis 2014;73:208793. doi:10.1136/annrheumdis-2013-203716.

[5] Clements PJ, Lachenbruch PA, Seibold JR, Zee B, Steen VD, Brennan P, et al. Skin thickness score in systemic sclerosis: an assessment of interobserver variability in 3 independent studies. J Rheumatol 1993;20:1892-6.

[6] Walker UA, Tyndall A, Czirjak L, Denton C, Farge-Bancel D, Kowal-Bielecka O, et al. Clinical risk assessment of organ manifestations in systemic sclerosis: a report from the EULAR Scleroderma Trials And Research group database. Ann Rheum Dis 2007;66:754-63. doi:10.1136/ard.2006.062901.

[7] Mihai C, Landewe R, van der Heijde D, Walker UA, Constantin PI, Gherghe AM, et al. Digital ulcers predict a worse disease course in patients with systemic sclerosis. Ann Rheum Dis 2015. doi:10.1136/annrheumdis-2014-205897.

[8] Galiè N, Humbert M, Vachiery J-L, Gibbs S, Lang I, Torbicki A, et al. 2015 ESC/ERS Guidelines for the diagnosis and treatment of pulmonary hypertension: The Joint Task Force for the Diagnosis and Treatment of Pulmonary Hypertension of the European Society of Cardiology (ESC) and the European Respiratory Society (ERS): Endorsed by: Association for European Paediatric and Congenital Cardiology (AEPC), International Society for Heart and Lung Transplantation (ISHLT). Eur Respir J 2015;46:903-75. doi:10.1183/13993003.01032-2015.

[9] Mukerjee D, St George D, Coleiro B, Knight C, Denton CP, Davar J, et al. Prevalence and outcome in systemic sclerosis associated pulmonary arterial hypertension: application of a registry approach. Ann Rheum Dis 2003;62:1088-93.

[10] Hachulla E, de Groote P, Gressin V, Sibilia J, Diot E, Carpentier P, et al. The three-year incidence of pulmonary arterial hypertension associated with systemic sclerosis in a multicenter nationwide longitudinal study in France. Arthritis Rheum 2009;60:1831-9. doi:10.1002/art.24525.

[11] M. Hassoun P. Lung involvement in systemic sclerosis. Presse Médicale 2011;40:e25-e39. doi:10.1016/j.lpm.2010.08.006.

[12] Coghlan JG, Denton CP, Grunig E, Bonderman D, Distler O, Khanna D, et al. Evidence-based detection of pulmonary arterial hypertension in systemic sclerosis: the DETECT study. Ann Rheum Dis 2014;73:1340-9. doi:10.1136/annrheumdis-2013-203301.

[13] Nihtyanova SI, Schreiber BE, Ong VH, Rosenberg D, Moinzadeh P, Coghlan JG, et al. Prediction of pulmonary complications and long-term survival in systemic sclerosis. Arthritis Rheumatol Hoboken NJ 2014;66:1625-35. doi:10.1002/art.38390.

[14] Fischer A, Swigris JJ, Groshong SD, Cool CD, Sahin H, Lynch DA, et al. Clinically Significant Interstitial Lung Disease in Limited SclerodermaHistopathology, Clinical Features, and Survival. CHEST J 2008;134:601-5.

[15] Papagoras C, Achenbach K, Tsifetaki N, Tsiouris S, Fotopoulos A, Drosos AA. Heart involvement in systemic sclerosis: a combined echocardiographic and scintigraphic study. Clin Rheumatol 2014;33:1105-11. doi:10.1007/s10067-014-2666-3. 
[16] Marie I, Leroi A-M, Menard J-F, Levesque H, Quillard M, Ducrotte P. Fecal calprotectin in systemic sclerosis and review of the literature. Autoimmun Rev 2015;14:547-54. doi:10.1016/j.autrev.2015.01.018.

[17] De Groote P, Gressin V, Hachulla E, Carpentier P, Guillevin L, Kahan A, et al. Evaluation of cardiac abnormalities by Doppler echocardiography in a large nationwide multicentric cohort of patients with systemic sclerosis. Ann Rheum Dis 2008;67:31-6.

[18] Avouac J, Walker UA, Hachulla E, Riemekasten G, Cuomo G, Carreira PE, et al. Joint and tendon involvement predict disease progression in systemic sclerosis: a EUSTAR prospective study. Ann Rheum Dis 2014. doi:10.1136/annrheumdis-2014-205295.

[19] Steen VD. Scleroderma renal crisis. Rheum Dis Clin North Am 2003;29:315-33.

[20] Mouthon L, Bussone G, Berezné A, Noël L-H, Guillevin L. Scleroderma renal crisis. J Rheumatol 2014;41:1040-8. doi:10.3899/jrheum.131210.

[21] Amaral TN, Peres FA, Lapa AT, Marques-Neto JF, Appenzeller S. Neurologic involvement in scleroderma: A systematic review. Semin Arthritis Rheum 2013;43:335-47. doi:10.1016/j.semarthrit.2013.05.002.

[22] Diab S, Dostrovsky N, Hudson M, Tatibouet S, Fritzler MJ, Baron M, et al. Systemic Sclerosis Sine Scleroderma: A Multicenter Study of 1417 Subjects. J Rheumatol 2014;41:2179-85.

[23] Marangoni RG, Rocha LF, Del Rio APT, Yoshinari NH, Marques-Neto JF, Sampaio-Barros PD. Systemic sclerosis sine scleroderma: distinct features in a large Brazilian cohort. Rheumatology 2013;52:1520-4. doi:10.1093/rheumatology/ket163.

[24] Bhansing KJ, Lammens M, Knaapen HK, van Riel PL, van Engelen BG, Vonk MC. Sclerodermapolymyositis overlap syndrome versus idiopathic polymyositis and systemic sclerosis: a descriptive study on clinical features and myopathology. Arthritis Res Ther 2014;16:R111.

[25] Guillen-Del Castillo A, Pilar Simeón-Aznar C, Fonollosa-Pla V, Alonso-Vila S, Reverte-Vinaixa MM, Muñoz X, et al. Good outcome of interstitial lung disease in patients with scleroderma associated to anti-PM/Scl antibody. Semin Arthritis Rheum 2014;44:331-7. doi:10.1016/j.semarthrit.2014.07.002.

[26] Marie I. [Systemic sclerosis and occupational exposure: towards an extension of legal recognition as occupational disorder in 2014?]. Rev Médecine Interne Fondée Par Société Natl Francaise Médecine Interne 2014;35:631-5. doi:10.1016/j.revmed.2014.04.002.

[27] Martin J-E, Broen JC, Carmona FD, Teruel M, Simeon CP, Vonk MC, et al. Identification of CSK as a systemic sclerosis genetic risk factor through Genome Wide Association Study follow-up. Hum Mol Genet 2012;21:2825-35. doi:10.1093/hmg/dds099.

[28] Radstake TRDJ, Gorlova O, Rueda B, Martin J-E, Alizadeh BZ, Palomino-Morales R, et al. Genomewide association study of systemic sclerosis identifies CD247 as a new susceptibility locus. Nat Genet 2010;42:426-9. doi:10.1038/ng.565.

[29] Rueda B, Gourh P, Broen J, Agarwal SK, Simeon C, Ortego-Centeno N, et al. BANK1 functional variants are associated with susceptibility to diffuse systemic sclerosis in Caucasians. Ann Rheum Dis 2010;69:700-5. doi:10.1136/ard.2009.118174.

[30] Dieudé P, Guedj M, Wipff J, Ruiz B, Hachulla E, Diot E, et al. STAT4 is a genetic risk factor for systemic sclerosis having additive effects with IRF5 on disease susceptibility and related pulmonary fibrosis. Arthritis Rheum 2009;60:2472-9. doi:10.1002/art.24688.

[31] Arnett FC, Gourh P, Shete S, Ahn CW, Honey RE, Agarwal SK, et al. Major histocompatibility complex (MHC) class II alleles, haplotypes and epitopes which confer susceptibility or protection in systemic sclerosis: analyses in 1300 Caucasian, African-American and Hispanic cases and 1000 controls. Ann Rheum Dis 2010;69:822-7. doi:10.1136/ard.2009.111906.

[32] Gilchrist FC, Bunn C, Foley PJ, Lympany PA, Black CM, Welsh KI, et al. Class II HLA associations with autoantibodies in scleroderma: a highly significant role for HLA-DP. Genes Immun 2001;2:76-81. doi:10.1038/sj.gene.6363734.

[33] Distler O, Del Rosso A, Giacomelli R, Cipriani P, Conforti ML, Guiducci S, et al. Angiogenic and angiostatic factors in systemic sclerosis: increased levels of vascular endothelial growth factor 
are a feature of the earliest disease stages and are associated with the absence of fingertip ulcers. Arthritis Res 2002;4:R11.

[34] Maurer B, Distler A, Suliman YA, Gay RE, Michel BA, Gay S, et al. Vascular endothelial growth factor aggravates fibrosis and vasculopathy in experimental models of systemic sclerosis. Ann Rheum Dis 2014;73:1880-7. doi:10.1136/annrheumdis-2013-203535.

[35] Manetti M, Guiducci S, Romano E, Bellando-Randone S, Lepri G, Bruni C, et al. Increased plasma levels of the VEGF165b splice variant are associated with the severity of nailfold capillary loss in systemic sclerosis. Ann Rheum Dis 2013;72:1425-7. doi:10.1136/annrheumdis-2012-203183.

[36] Shirai Y, Okazaki Y, Inoue Y, Tamura Y, Yasuoka H, Takeuchi T, et al. Elevated Levels of Pentraxin 3 in Systemic Sclerosis: Associations With Vascular Manifestations and Defective Vasculogenesis: PTX3 and SSc Vasculopathy. Arthritis Rheumatol 2015;67:498-507. doi:10.1002/art.38953.

[37] Dumoitier N, Lofek S, Mouthon L. Pathophysiology of systemic sclerosis: state of the art in 2014. Presse Médicale Paris Fr 1983 2014;43:e267-278. doi:10.1016/j.lpm.2014.08.001.

[38] Kawakami T, Ihn H, Xu W, Smith E, LeRoy C, Trojanowska M. Increased expression of TGF-beta receptors by scleroderma fibroblasts: evidence for contribution of autocrine TGF-beta signaling to scleroderma phenotype. J Invest Dermatol 1998;110:47-51. doi:10.1046/j.15231747.1998.00073.x.

[39] Parel Y, Aurrand-Lions M, Scheja A, Dayer J-M, Roosnek E, Chizzolini C. Presence of CD4+CD8+ double-positive T cells with very high interleukin-4 production potential in lesional skin of patients with systemic sclerosis. Arthritis Rheum 2007;56:3459-67. doi:10.1002/art.22927.

[40] Luzina IG, Atamas SP, Wise R, Wigley FM, Choi J, Xiao HQ, et al. Occurrence of an activated, profibrotic pattern of gene expression in lung CD8+ T cells from scleroderma patients. Arthritis Rheum 2003;48:2262-74. doi:10.1002/art.11080.

[41] Sato S, Fujimoto M, Hasegawa M, Takehara K. Altered blood B lymphocyte homeostasis in systemic sclerosis: expanded naive $B$ cells and diminished but activated memory B cells. Arthritis Rheum 2004;50:1918-27. doi:10.1002/art.20274.

[42] Becker MO, Kill A, Kutsche M, Guenther J, Rose A, Tabeling C, et al. Vascular receptor autoantibodies in pulmonary arterial hypertension associated with systemic sclerosis. Am J Respir Crit Care Med 2014;190:808-17. doi:10.1164/rccm.201403-04420C.

[43] Sato S, Hasegawa M, Takehara K. Serum levels of interleukin- 6 and interleukin-10 correlate with total skin thickness score in patients with systemic sclerosis. J Dermatol Sci 2001;27:140-6.

[44] Chizzolini C. T cells, B cells, and polarized immune response in the pathogenesis of fibrosis and systemic sclerosis. Curr Opin Rheumatol 2008;20:707-12. doi:10.1097/BOR.0b013e32830c45ae.

[45] Van Bon L, Affandi AJ, Broen J, Christmann RB, Marijnissen RJ, Stawski L, et al. Proteome-wide Analysis and CXCL4 as a Biomarker in Systemic Sclerosis. N Engl J Med 2014;370:433-43. doi:10.1056/NEJMoa1114576.

[46] Mehra S, Walker J, Patterson K, Fritzler MJ. Autoantibodies in systemic sclerosis. Autoimmun Rev 2013;12:340-54. doi:10.1016/j.autrev.2012.05.011.

[47] Van den Hoogen F, Khanna D, Fransen J, Johnson SR, Baron M, Tyndall A, et al. 2013 classification criteria for systemic sclerosis: an American college of rheumatology/European league against rheumatism collaborative initiative. Ann Rheum Dis 2013;72:1747-55. doi:10.1136/annrheumdis-2013-204424.

[48] Sobanski V, Dauchet L, Lefèvre G, Lambert M, Morell-Dubois S, Sy T, et al. Prevalence of AntiRNA Polymerase III Antibodies in Systemic Sclerosis: New Data From a French Cohort and a Systematic Review and Meta-Analysis: Prevalence of Anti-RNAP III in SSc. Arthritis Rheumatol 2014;66:407-17. doi:10.1002/art.38219.

[49] Hesselstrand R, Scheja A, Wuttge D. Scleroderma renal crisis in a Swedish systemic sclerosis cohort: survival, renal outcome, and RNA polymerase III antibodies as a risk factor. Scand J Rheumatol 2012;41:39-43. doi:10.3109/03009742.2011.610032.

[50] Nikpour M, Hissaria P, Byron J, Sahhar J, Micallef M, Paspaliaris W, et al. Prevalence, correlates and clinical usefulness of antibodies to RNA polymerase III in systemic sclerosis: a cross-sectional analysis of data from an Australian cohort. Arthritis Res Ther 2011;13:R211. 
[51] Moinzadeh P, Fonseca C, Hellmich M, Shah AA, Chighizola C, Denton CP, et al. Association of antiRNA polymerase III autoantibodies and cancer in scleroderma. Arthritis Res Ther 2014;16:R53.

[52] Graf SW, Hakendorf P, Lester S, Patterson K, Walker JG, SMITH M, et al. South Australian Scleroderma Register: autoantibodies as predictive biomarkers of phenotype and outcome. Int J Rheum Dis 2012;15:102-9.

[53] Mitri GM, Lucas M, Fertig N, Steen VD, Medsger TA. A comparison between anti-Th/To- and anticentromere antibody-positive systemic sclerosis patients with limited cutaneous involvement. Arthritis Rheum 2003;48:203-9. doi:10.1002/art.10760.

[54] Ceribelli A, Cavazzana I, Franceschini F, Airò P, Tincani A, Cattaneo R, et al. Anti-Th/To are common antinucleolar autoantibodies in Italian patients with scleroderma. J Rheumatol 2010;37:2071-5. doi:10.3899/jrheum.100316.

[55] Sharif R, Fritzler MJ, Mayes MD, Gonzalez EB, McNearney TA, Draeger H, et al. Anti-fibrillarin antibody in African American patients with systemic sclerosis: immunogenetics, clinical features, and survival analysis. J Rheumatol 2011;38:1622-30. doi:10.3899/jrheum.110071.

[56] Aggarwal R, Lucas M, Fertig N, Oddis CV, Medsger TA. Anti-U3 RNP autoantibodies in systemic sclerosis. Arthritis Rheum 2009;60:1112-8. doi:10.1002/art.24409.

[57] LeRoy EC, Medsger TA. Criteria for the classification of early systemic sclerosis. J Rheumatol 2001;28:1573-6.

[58] Koenig M, Joyal F, Fritzler MJ, Roussin A, Abrahamowicz M, Boire G, et al. Autoantibodies and microvascular damage are independent predictive factors for the progression of Raynaud's phenomenon to systemic sclerosis: a twenty-year prospective study of 586 patients, with validation of proposed criteria for early systemic sclerosis. Arthritis Rheum 2008;58:3902-12. doi:10.1002/art.24038.

[59] Valentini G, Cuomo G, Abignano G, Petrillo A, Vettori S, Capasso A, et al. Early systemic sclerosis: assessment of clinical and pre-clinical organ involvement in patients with different disease features. Rheumatol Oxf Engl 2011;50:317-23. doi:10.1093/rheumatology/keq176.

[60] Clements PJ, Tan M, McLaughlin VV, Oudiz RJ, Tapson VF, Channick RN, et al. The pulmonary arterial hypertension quality enhancement research initiative: comparison of patients with idiopathic PAH to patients with systemic sclerosis-associated PAH. Ann Rheum Dis 2012;71:24952. doi:10.1136/annrheumdis-2011-200265.

[61] Chung L, Liu J, Parsons L, Hassoun PM, McGoon M, Badesch DB, et al. Characterization of connective tissue disease-associated pulmonary arterial hypertension from REVEAL: identifying systemic sclerosis as a unique phenotype. Chest 2010;138:1383-94. doi:10.1378/chest.10-0260.

[62] Chung L, Farber HW, Benza R, Miller DP, Parsons L, Hassoun PM, et al. Unique predictors of mortality in patients with pulmonary arterial hypertension associated with systemic sclerosis in the reveal registry. CHEST J 2014;146:1494-504.

[63] Winstone TA, Assayag D, Wilcox PG, Dunne JV, Hague CJ, Leipsic J, et al. Predictors of mortality and progression in scleroderma-associated interstitial lung disease: a systematic review. Chest 2014;146:422-36. doi:10.1378/chest.13-2626.

[64] Iudici M, Moroncini G, Cipriani P, Giacomelli R, Gabrielli A, Valentini G. Where are we going in the management of interstitial lung disease in patients with systemic sclerosis? Autoimmun Rev 2015;14:575-8. doi:10.1016/j.autrev.2015.02.002.

[65] Kowal-Bielecka O, Landewe R, Avouac J, Chwiesko S, Miniati I, Czirjak L, et al. EULAR recommendations for the treatment of systemic sclerosis: a report from the EULAR Scleroderma Trials and Research group (EUSTAR). Ann Rheum Dis 2009;68:620-8. doi:10.1136/ard.2008.096677.

[66] Thompson AE, Shea B, Welch V, Fenlon D, Pope JE. Calcium-channel blockers for Raynaud's phenomenon in systemic sclerosis. Arthritis Rheum 2001;44:1841-7. doi:10.1002/15290131(200108)44:8<1841::AID-ART322>3.0.CO;2-8.

[67] Pope J, Fenlon D, Thompson A, Shea B, Furst D, Wells G, et al. lloprost and cisaprost for Raynaud's phenomenon in progressive systemic sclerosis. Cochrane Database Syst Rev 2000:CD000953. doi:10.1002/14651858.CD000953. 
[68] Scorza R, Caronni M, Mascagni B, Berruti V, Bazzi S, Micallef E, et al. Effects of long-term cyclic iloprost therapy in systemic sclerosis with Raynaud's phenomenon. A randomized, controlled study. Clin Exp Rheumatol 2001;19:503-8.

[69] Rademaker M, Cooke ED, Almond NE, Beacham JA, Smith RE, Mant TG, et al. Comparison of intravenous infusions of iloprost and oral nifedipine in treatment of Raynaud's phenomenon in patients with systemic sclerosis: a double blind randomised study. BMJ 1989;298:561-4.

[70] Roustit M, Blaise S, Allanore Y, Carpentier PH, Caglayan E, Cracowski J-L. Phosphodiesterase-5 inhibitors for the treatment of secondary Raynaud's phenomenon: systematic review and metaanalysis of randomised trials. Ann Rheum Dis 2013;72:1696-9. doi:10.1136/annrheumdis-2012202836.

[71] Hughes M, Ong VH, Anderson ME, Hall F, Moinzadeh P, Griffiths B, et al. Consensus best practice pathway of the UK Systemic Sclerosis Study Group: digital vasculopathy in systemic sclerosis. Rheumatology 2015. doi:10.1093/rheumatology/kev201.

[72] Wigley FM, Seibold JR, Wise RA, McCloskey DA, Dole WP. Intravenous iloprost treatment of Raynaud's phenomenon and ischemic ulcers secondary to systemic sclerosis. J Rheumatol 1992;19:1407-14.

[73] Korn JH, Mayes M, Matucci Cerinic M, Rainisio M, Pope J, Hachulla E, et al. Digital ulcers in systemic sclerosis: prevention by treatment with bosentan, an oral endothelin receptor antagonist. Arthritis Rheum 2004;50:3985-93. doi:10.1002/art.20676.

[74] Matucci-Cerinic M, Denton CP, Furst DE, Mayes MD, Hsu VM, Carpentier P, et al. Bosentan treatment of digital ulcers related to systemic sclerosis: results from the RAPIDS-2 randomised, double-blind, placebo-controlled trial. Ann Rheum Dis 2011;70:32-8. doi:10.1136/ard.2010.130658.

[75] Tingey T, Shu J, Smuczek J, Pope J. Meta-analysis of healing and prevention of digital ulcers in systemic sclerosis. Arthritis Care Res 2013;65:1460-71. doi:10.1002/acr.22018.

[76] Hachulla E, Hatron P-Y, Carpentier P, Agard C, Chatelus E, Jego P, et al. Efficacy of sildenafil on ischaemic digital ulcer healing in systemic sclerosis: the placebo-controlled SEDUCE study. Ann Rheum Dis 2015. doi:10.1136/annrheumdis-2014-207001.

[77] Fernandes das Neves M, Oliveira S, Amaral MC, Delgado Alves J. Treatment of systemic sclerosis with tocilizumab. Rheumatology 2015;54:371-2. doi:10.1093/rheumatology/keu435.

[78] Steen VD, Costantino JP, Shapiro AP, Medsger TA. Outcome of renal crisis in systemic sclerosis: relation to availability of angiotensin converting enzyme (ACE) inhibitors. Ann Intern Med 1990;113:352-7.

[79] Steen VD. Kidney involvement in systemic sclerosis. Presse Médicale 2014;43:e305-e314. doi:10.1016/j.lpm.2014.02.031.

[80] Hudson M, Baron M, Tatibouet S, Furst DE, Khanna D. Exposure to ACE inhibitors prior to the onset of scleroderma renal crisis-Results from the International Scleroderma Renal Crisis Survey. Semin Arthritis Rheum 2014;43:666-72. doi:10.1016/j.semarthrit.2013.09.008.

[81] Sanges S, Launay D, Rhee RL, Sitbon O, Hachulla É, Mouthon L, et al. A prospective study of the 6 min walk test as a surrogate marker for haemodynamics in two independent cohorts of treatment-naïve systemic sclerosis-associated pulmonary arterial hypertension. Ann Rheum Dis 2015:annrheumdis-2015-207336. doi:10.1136/annrheumdis-2015-207336.

[82] Girgis RE, Mathai SC, Krishnan JA, Wigley FM, Hassoun PM. Long-term outcome of bosentan treatment in idiopathic pulmonary arterial hypertension and pulmonary arterial hypertension associated with the scleroderma spectrum of diseases. J Heart Lung Transplant 2005;24:162631.

[83] Pulido T, Adzerikho I, Channick RN, Delcroix M, Galiè N, Ghofrani H-A, et al. Macitentan and morbidity and mortality in pulmonary arterial hypertension. N Engl J Med 2013;369:809-18. doi:10.1056/NEJMoa1213917.

[84] Badesch DB, Tapson VF, McGoon MD, Brundage BH, Rubin LJ, Wigley FM, et al. Continuous intravenous epoprostenol for pulmonary hypertension due to the scleroderma spectrum of disease. A randomized, controlled trial. Ann Intern Med 2000;132:425-34. 
[85] Galiè N, Corris PA, Frost A, Girgis RE, Granton J, Jing ZC, et al. Updated Treatment Algorithm of Pulmonary Arterial Hypertension. J Am Coll Cardiol 2013;62:D60-D72. doi:10.1016/j.jacc.2013.10.031.

[86] Tashkin DP, Elashoff R, Clements PJ, Goldin J, Roth MD, Furst DE, et al. Cyclophosphamide versus placebo in scleroderma lung disease. N Engl J Med 2006;354:2655-66.

[87] Hoyles RK, Ellis RW, Wellsbury J, Lees B, Newlands P, Goh NSL, et al. A multicenter, prospective, randomized, double-blind, placebo-controlled trial of corticosteroids and intravenous cyclophosphamide followed by oral azathioprine for the treatment of pulmonary fibrosis in scleroderma. Arthritis Rheum 2006;54:3962-70. doi:10.1002/art.22204.

[88] Nannini C, West CP, Erwin PJ, Matteson EL. Effects of cyclophosphamide on pulmonary function in patients with scleroderma and interstitial lung disease: a systematic review and meta-analysis of randomized controlled trials and observational prospective cohort studies. Arthritis Res Ther 2008;10:R124.

[89] Yilmaz N, Can M, Kocakaya D, Karakurt S, Yavuz S. Two-year experience with mycophenolate mofetil in patients with scleroderma lung disease: a case series. Int J Rheum Dis 2014;17:923-8. doi:10.1111/1756-185X.12399.

[90] Koutroumpas A, Ziogas A, Alexiou I, Barouta G, Sakkas LI. Mycophenolate mofetil in systemic sclerosis-associated interstitial lung disease. Clin Rheumatol 2010;29:1167-8. doi:10.1007/s10067-010-1498-z.

[91] Keir GJ, Maher TM, Ming D, Abdullah R, de Lauretis A, Wickremasinghe M, et al. Rituximab in severe, treatment-refractory interstitial lung disease. Respirol Carlton Vic 2014;19:353-9. doi:10.1111/resp.12214.

[92] Daoussis D, Liossis S-NC, Tsamandas AC, Kalogeropoulou C, Paliogianni F, Sirinian C, et al. Effect of long-term treatment with rituximab on pulmonary function and skin fibrosis in patients with diffuse systemic sclerosis. Clin Exp Rheumatol 2012;30:S17-22.

[93] Giuggioli D, Lumetti F, Colaci M, Fallahi P, Antonelli A, Ferri C. Rituximab in the treatment of patients with systemic sclerosis. Our experience and review of the literature. Autoimmun Rev 2015;14:1072-8. doi:10.1016/j.autrev.2015.07.008.

[94] Jordan S, Maurer B, Toniolo M, Michel B, Distler O. Performance of the new ACR/EULAR classification criteria for systemic sclerosis in clinical practice. Rheumatology 2015;54:1454-8. doi:10.1093/rheumatology/keu530.

[95] Khanna D, Saggar R, Mayes MD, Abtin F, Clements PJ, Maranian P, et al. A one-year, phase I/Ila, open-label pilot trial of imatinib mesylate in the treatment of systemic sclerosis-associated active interstitial lung disease. Arthritis Rheum 2011;63:3540-6. doi:10.1002/art.30548.

[96] Fraticelli P, Gabrielli B, Pomponio G, Valentini G, Bosello S, Riboldi P, et al. Low-dose oral imatinib in the treatment of systemic sclerosis interstitial lung disease unresponsive to cyclophosphamide: a phase II pilot study. Arthritis Res Ther 2014;16:R144.

[97] Le EN, Wigley FM, Shah AA, Boin F, Hummers LK. Long-term experience of mycophenolate mofetil for treatment of diffuse cutaneous systemic sclerosis. Ann Rheum Dis 2011;70:1104-7. doi:10.1136/ard.2010.142000.

[98] Mendoza FA, Nagle SJ, Lee JB, Jimenez SA. A prospective observational study of mycophenolate mofetil treatment in progressive diffuse cutaneous systemic sclerosis of recent onset. J Rheumatol 2012;39:1241-7. doi:10.3899/jrheum.111229.

[99] Poelman CL, Hummers LK, Wigley FM, Anderson C, Boin F, Shah AA. Intravenous immunoglobulin may be an effective therapy for refractory, active diffuse cutaneous systemic sclerosis. J Rheumatol 2015;42:236-42. doi:10.3899/jrheum.140833.

[100] Takehara K, Ihn H, Sato S. A randomized, double-blind, placebo-controlled trial: intravenous immunoglobulin treatment in patients with diffuse cutaneous systemic sclerosis. Clin Exp Rheumatol 2013;31:151-6.

[101] Bosello SL, De Luca G, Rucco M, Berardi G, Falcione M, Danza FM, et al. Long-term efficacy of $B$ cell depletion therapy on lung and skin involvement in diffuse systemic sclerosis. Semin Arthritis Rheum 2015;44:428-36. doi:10.1016/j.semarthrit.2014.09.002. 
[102] Huang J, Beyer C, Palumbo-Zerr K, Zhang Y, Ramming A, Distler A, et al. Nintedanib inhibits fibroblast activation and ameliorates fibrosis in preclinical models of systemic sclerosis. Ann Rheum Dis 2015. doi:10.1136/annrheumdis-2014-207109.

[103] Gordon JK, Martyanov V, Magro C, Wildman HF, Wood TA, Huang W-T, et al. Nilotinib (Tasigna $^{\mathrm{TM}}{ }^{\text {) }}$ in the treatment of early diffuse systemic sclerosis: an open-label, pilot clinical trial. Arthritis Res Ther 2015;17. doi:10.1186/s13075-015-0721-3.

[104] Rice LM, Padilla CM, McLaughlin SR, Mathes A, Ziemek J, Goummih S, et al. Fresolimumab treatment decreases biomarkers and improves clinical symptoms in systemic sclerosis patients. J Clin Invest 2015;125:2795-807. doi:10.1172/JCI77958.

[105] Burt RK, Shah SJ, Dill K, Grant T, Gheorghiade M, Schroeder J, et al. Autologous nonmyeloablative haemopoietic stem-cell transplantation compared with pulse cyclophosphamide once per month for systemic sclerosis (ASSIST): an open-label, randomised phase 2 trial. Lancet Lond Engl 2011;378:498-506. doi:10.1016/S0140-6736(11)60982-3.

[106] Van Laar JM, Farge D, Sont JK, Naraghi K, Marjanovic Z, Larghero J, et al. Autologous hematopoietic stem cell transplantation vs intravenous pulse cyclophosphamide in diffuse cutaneous systemic sclerosis: a randomized clinical trial. JAMA 2014;311:2490-8. doi:10.1001/jama.2014.6368.

[107] Mierau R, Moinzadeh P, Riemekasten G, Melchers I, Meurer M, Reichenberger F, et al. Frequency of disease-associated and other nuclear autoantibodies in patients of the German Network for Systemic Scleroderma: correlation with characteristic clinical features. Arthritis Res Ther 2011;13:R172. 
Table 1 : Main clinical features of Systemic sclerosis (SSc) according to phenotypes and auto-antibodies $[6,52,107]$

\begin{tabular}{|c|c|c|c|c|c|}
\hline & $\begin{array}{l}\text { Limited } \\
\text { cutaneous } \\
\text { SSc }\end{array}$ & $\begin{array}{c}\text { Diffuse } \\
\text { cutaneous } \\
\text { SSc }\end{array}$ & $\begin{array}{c}\text { Anti- } \\
\text { centromeres } \\
\text { antibodies }\end{array}$ & $\begin{array}{c}\text { Anti- } \\
\text { Topoisomerase } \\
\text { I } \\
\text { antibodies }\end{array}$ & $\begin{array}{c}\text { Anti-RNA } \\
\text { polymerase } \\
\text { III } \\
\text { antibodies }\end{array}$ \\
\hline Digital ulcers & $33-38 \%$ & $43 \%$ & $18-42 \%$ & $40-45 \%$ & $20 \%$ \\
\hline $\begin{array}{l}\text { Interstitial lung } \\
\text { disease }\end{array}$ & $35 \%$ & $53 \%$ & $13-21 \%$ & $30-60 \%$ & $20 \%$ \\
\hline Renal crisis & $1 \%$ & $4-11 \%$ & $1 \%$ & $2-4 \%$ & $20 \%$ \\
\hline $\begin{array}{l}\text { Pulmonary arterial } \\
\text { hypertension } \\
\text { (without pulmonary } \\
\text { fibrosis) }\end{array}$ & $9 \%$ & $6 \%$ & $5-10 \%$ & $13-17 \%$ & $10 \%$ \\
\hline $\begin{array}{l}\text { Oesophagus } \\
\text { involvement }\end{array}$ & $67 \%$ & $68 \%$ & $64-71 \%$ & $68 \%$ & $60 \%$ \\
\hline Cardiac involvement & $6 \%$ & $8 \%$ & $9 \%$ & $17 \%$ & $15 \%$ \\
\hline $\begin{array}{l}\text { Muscular } \\
\text { involvement }\end{array}$ & $22 \%$ & $37 \%$ & $23-40 \%$ & $32-50 \%$ & $50 \%$ \\
\hline
\end{tabular}


Table 2: Risk factors/parameters associated to pulmonary arterial hypertension (PAH) in patients with systemic sclerosis (SSc) [11]

\section{Clinical parameters}

- Limited cutaneous SSc

- Older age at SSc symptoms onset

- Digital ulcers

- Capillary loss on capillaroscopy

- Multiple telangiectasia

\section{Respiratory parameters}

- Decreased DLCO (Diffusion )

- FVC/DLCO >1.6

\section{Biological parameters}

- High serum NT-pro BNP levels (brain natriuretic peptide)

- Anti-RNP antibodies 
Table 3: Systemic sclerosis (SSc) classification criteria by the American College of Rheumatology/European League Against Rheumatism" in 2013 [47]

\begin{tabular}{|c|c|c|}
\hline Item & Sub-item & Score \\
\hline $\begin{array}{l}\text { Skin thickening of the fingers of } \\
\text { both hands extending proximal to } \\
\text { the } \\
\text { metacarpophalangeal joints } \\
\text { (sufficient criterion) }\end{array}$ & & 9 \\
\hline $\begin{array}{l}\text { Skin thickening of the fingers } \\
\text { (only count the highest score) }\end{array}$ & $\begin{array}{l}\text { - } \\
\text { Puffy fingers (2) } \\
\text { Sclerodactyly of the fingers } \\
\text { (distal to the } \\
\text { metacarpophalangeal joints but } \\
\text { proximal to the proximal } \\
\text { interphalangeal joints) }\end{array}$ & $\begin{array}{l}2 \\
4\end{array}$ \\
\hline $\begin{array}{l}\text { Fingertip lesions } \\
\text { (only count the highest score }\end{array}$ & $\begin{array}{ll}\text { - } & \text { Digital tip ulcers (2) } \\
\text { - } & \text { Fingertip pitting scars (3) }\end{array}$ & $\begin{array}{l}2 \\
3\end{array}$ \\
\hline Telangiectasia & & 2 \\
\hline Abnormal nailfold capillaries & & 2 \\
\hline $\begin{array}{l}\text { Pulmonary arterial hypertension } \\
\text { and/or interstitial lung disease }\end{array}$ & $\begin{array}{ll}\text { - } & \text { Pulmonary arterial } \\
& \text { hypertension (2) } \\
\text { - } & \text { Interstitial lung disease (2) }\end{array}$ & $\begin{array}{c}2 \\
\text { (maximum) }\end{array}$ \\
\hline Raynaud's phenomenon & & 3 \\
\hline SSc-related auto-antibodies & $\begin{array}{l}\text { - Anti-centromere (1) } \\
\text { - Anti-topoisomerase I (anti-Scl- } \\
\text { 70) (1) } \\
\text { - Anti-RNA polymerase III) (1) } \\
\text { [maximum score is 3] }\end{array}$ & $\begin{array}{c}3 \\
\text { (maximum) }\end{array}$ \\
\hline
\end{tabular}

The total score is determined by adding the maximum weight (score) in each category. Patients with a total score of $\geq 9$ are classified as having definite systemic sclerosis. Sensibility 91\% [CI95\% 87\%; 94\%] and Specificity 92\% [CI95\% 86\%; 96\%]. 